Research Paper

\title{
Some factors affecting tannase production by Aspergillus niger Van Tieghem
}

\author{
Hamada A. Aboubakr, Malak A. El-Sahn, Amr A. El-Banna \\ Department of Food Science and Technology, Faculty of Agriculture, Alexandria University, Alexandria, \\ Egypt.
}

Submitted: September 18, 2011; Approved: July 23, 2012.

\begin{abstract}
One variable at a time procedure was used to evaluate the effect of qualitative variables on the production of tannase from Aspergillus niger Van Tieghem. These variables including: fermentation technique, agitation condition, tannins source, adding carbohydrates incorporation with tannic acid, nitrogen source type and divalent cations. Submerged fermentation under intermittent shaking gave the highest total tannase activity. Maximum extracellular tannase activity ( 305 units $/ 50 \mathrm{~mL}$ ) was attained in medium containing tannic acid as tannins source and sodium nitrate as nitrogen source at $30{ }^{\circ} \mathrm{C}$ for $96 \mathrm{~h}$. All added carbohydrates showed significant adverse effects on the production of tannase. All tested divalent cations significantly decreased tannase production. Moreover, split plot design was carried out to study the effect of fermentation temperature and fermentation time on tannase production. The results indicated maximum tannase production $(312.7 \mathrm{units} / 50 \mathrm{~mL})$ at $35^{\circ} \mathrm{C}$ for $96 \mathrm{~h}$. In other words, increasing fermentation temperature from $30^{\circ} \mathrm{C}$ to $35^{\circ} \mathrm{C}$ resulted in increasing tannase production.
\end{abstract}

Key words: tannase, Aspergillus niger Van Tieghem, factors affecting tannase production, split plot design.

\section{Introduction}

Tannin acyl hydrolase (EC 3.1.1.20) which is commonly referred to as tannase is one of the important hydrolytic microbial enzymes (Bajpai and Patil, 1997). It has several applications in food, animal feed, pharmaceutical, chemical and leather industries (Aguilar and GutiérrezSanchez, 2001). Van Teighem accidentally discovered this unique enzyme in 1867 . He was the first to demonstrate that the formation of gallic acid during fermentation of gall nut (which contains high levels of tannins) is due to the action of Aspergillus niger tannase (Aguilar et al., 2007; Albertse, 2002). Tannase activity has been detected in bacteria and fungi (Albertse, 2002; Banerjee and Pati, 2007; Rodriguez et al., 2008).

Several fermentation systems have been developed for the production of tannase from fungi using various production media. These systems can be divided into liquid surface fermentation (LSF), submerged fermentation $(\mathrm{SmF})$, solid-state fermentation (SSF) and modified solid state fermentation, MSSF (Kar and Banerjee, 2000; Manjit et al., 2008; Rana and Bhat, 2005; Sharma et al., 2008).

The effect of oxygenation on Rhizopus oryzae tannase production in modified Czapek-Dox's minimal medium (MCDM medium) under various conditions (shaking, intermittent shaking, and stationary) was studied (Hadi et al., 1994). Results showed that tannase production was at maximum under shaking condition using $\mathrm{SmF}$ technique. On the other hand, Kar and Banerjee (2000) reported that agitation is unfavorable for tannase synthesis by Rhizopus oryzae and that maximum tannase secretion was obtained after $72 \mathrm{~h}$ of incubation under stationary condition using MSSF .

There are many reports on the influence of medium components and growth conditions on the production of tannase by fungi (Banerjee et al., 2005; Chatterjee et al., 1996). Production of tannase using MSSF by a co-culture of Rhizopus oryzae and Aspergillus foetidus was studied. Tannin-rich substrates (powdered fruits of Terminalia chebula and powdered pod cover of Caesalpinia digyna)

Send correspondence to A.A. El-Banna. Department of Food Science and Technology, Faculty of Agriculture, Alexandria University, Aflaton St., El-Shatby, P.O. Box 21545 Alexandria, Egypt. E-mail: amrbanna47@gmail.com. 
were used in the process. Different process parameters for maximum production of tannase were optimized through media engineering. Optimum conditions were: $30^{\circ} \mathrm{C}, 80 \%$ relative humidity, $\mathrm{pH} 5$ and incubation time of $48 \mathrm{~h}$ (Banerjee et al., 2005). The best favorable conditions for tannase production by SSF using Rhizopus oryzae were: initial pH 5 with 4 days of incubation period at $40{ }^{\circ} \mathrm{C}$ and $72 \%$ humidity and $10 \mathrm{~g}$ wheat bran soaked $2.5 \%$ tannic acid (Chatterjee et al., 1996).

Belmares-Cerda et al. (2003) used several carbon sources (gallic acid, glucose, tannic acid, and infusions from creosote bush, pecan peels and sorghum) to produce tannase by Aspergillus niger PSH . The highest tannase activity was obtained when infusion of creosote bush was used as a carbon source.

The effect of adding $1 \%(\mathrm{w} / \mathrm{v})$ different sugars (fructose, galactose, maltose and sucrose) incorporation with $2 \%$ tannic acid on Rhizopus oryzae tannase production in MCDM medium was studied (Hadi et al., 1994). The results showed that the maximum tannase production was attained with tannic acid without sugar addition. Various inorganic and organic nitrogen sources were tested to enhance tannase synthesis by fungi. Some investigators reported the stimulation effect of inorganic nitrogen sources (Hadi et al., 1994; Sharma et al., 2007). Hadi et al. (1994) tested the effect of ammonium sulfate, ammonium nitrate, sodium nitrate, sodium nitrite and urea, incorporation into Czapek-Dox's medium on Rhizopus oryzae tannase productivity. Results revealed that sodium nitrate was found to be the best and the highest tannase production was attained at $0.05 \%$ sodium nitrate. Others reported the superiority of organic nitrogen sources (Huang and Borthwick, 2005; Manjit et al., 2008). The effect of various nitrogen sources (peptone, brew's cream, urea, potassium nitrate and sodium nitrate) on the Aspergillus SH6 tannase production was studied in a medium containing valonia tannins (ellagitannins) as a substrates. Results indicated that organic nitrogen sources were favorable to the degradation of tannins, specially peptone as nitrogen source, which delivered high tannase activity (Huang and Borthwick, 2005).

Bradoo et al. (1997) studied the effect of adding divalent cations to MCDM medium on tannase production by Aspergillus japonicas. Results showed that all tested divalent cations decreased tannase production.

The fermentation time needed for obtaining maximum tannase production by fungi varied from fungal strain to another. In general, the optimum fermentation time ranged from 24 to $150 \mathrm{~h}$. (Banerjee et al., 2001; Chatterjee et al., 1996). Many investigations revealed that fungal tannase production was peaked at the optimum incubation period. Afterwards, tannase production decreased gradually (Hadi et al., 1994; Huang and Borthwick, 2005; Kumar et al., 2007; Rodrigues et al., 2007). This might be due to catabolic repression and substrate scarcity in the medium (Hadi et al., 1994) or due to scarcity in nitrogen source
(Huang and Borthwick, 2005). Additionally, it may be owing to accumulation of toxic metabolites secreted during fermentation (Hadi et al., 1994; Kumar et al., 2007; Rodrigues et al., 2007).

Fermentation temperature affects microbial cellular growth, spore formation, germination, microbial physiology, and thus product formation. Therefore, maintenance of an optimal process temperature is considered as one of the major factors which affect the economics of the microbial enzymes production process (Banerjee et al., 2005). Different optimum incubation temperatures were used by researchers for the production of tannase by various fungi. The used temperatures ranged from $25^{\circ} \mathrm{C}$ to $42{ }^{\circ} \mathrm{C}$ (Chatterjee et al., 1996; Manjit et al., 2008).

In the present study, an effort was made to study the effect of qualitative variables (fermentation technique, agitation condition, tannins source, adding carbohydrates incorporation with tannic acid, type of nitrogen source and divalent cations) on the production of tannase by a newly isolate of Aspergillus niger Van Tieghem using OVAT procedure. Full factorial experiment using split plot design was carried out to study the effect of fermentation temperature and fermentation time on tannase production.

\section{Materials and Methods}

\section{Microorgaism}

Aspergillus niger Van Tieghem was selected as a potential producer of tannase after screening of 105 fungal isolates (Aboubakr et al., 2012). It was maintained on Potato Dextrose Agar (PDA) supplemented with $0.01 \%$ tannic acid (Bajpai and Patil, 1997).

\section{Chemicals}

All chemicals used were of analytical grade and obtained from Sigma, Aldrich, Merck and VEB Labor chemie Apolda (Germany); BDH, JUDEX chemicals, LAB M ${ }^{\mathrm{TM}}$ and Oxoid (England); Biolife (Italy); Chemapol (Czechoslovakia) and El-Nasr Pharmaceutical Chemicals Co. "ADWIC" (Egypt).

\section{Raw materials}

Several plant raw materials as well as industrial wastes which incorporated in the media for enzyme production were obtained from different sources at Alexandria, Egypt.

Wheat bran and all prepared plant raw materials were kept in tightly closed Kilner jars and maintained at room temperature in dry place. Pomegranate peels, persimmon fruits, unripe date fruits and river-red-gum leaves were washed with distilled water twice. After cutting or slicing, they were dried at $60{ }^{\circ} \mathrm{C}$ in hot air oven for 48 hours. The dried materials were then finely milled and sieved to pass 80 mesh screen. Soybean and seeds of cotton and flax were milled, defatted by hexane and screened to 80 mesh. 
Two synthetic solid supports were used in the solid state fermentation technique. Polyurethane foam (PUF) with bulk density $15 \mathrm{~kg} / \mathrm{m}^{3}$ was kindly supplied by Foam Industrial Company, Egypt. Synthetic sponge was obtained from Taki Vita Company, Egypt.

\section{Media}

The MCDM medium was prepared from the following ingredients $(\mathrm{g} / \mathrm{L})$ : tannic acid (10), $\mathrm{NaNO}_{3}(6), \mathrm{KCl}$ (0.52), $\mathrm{MgSO}_{4} 7 \mathrm{H}_{2} \mathrm{O}(0.52), \mathrm{KH}_{2} \mathrm{PO}_{4}(1.52), \mathrm{FeSO}_{4} 7 \mathrm{H}_{2} \mathrm{O}$ (0.01), $\mathrm{ZnSO}_{4} 7 \mathrm{H}_{2} \mathrm{O}(0.01)$ and $\mathrm{Cu}\left(\mathrm{NO}_{3}\right)_{2} 3 \mathrm{H}_{2} \mathrm{O}(0.01)$. The medium was adjusted at $\mathrm{pH} 4.5 \pm 0.2$ and sterilized at $121^{\circ} \mathrm{C}$ for $15 \mathrm{~min}$. The solution of tannic acid was sterilized separately by passing through MILLEX ${ }^{\mathbb{B}}$-OR membrane filter ( $33 \mathrm{~mm}$ diameter, $0.22 \mu \mathrm{m}$ pore size, Millipore, France) and adjusted separately at $\mathrm{pH} 4.5 \pm 0.2$, then added to the medium (Bradoo et al., 1996). Potato Dextrose Agar (PDA) supplemented with $0.01 \%$ tannic acid was used as maintenance medium (Bajpai and Patil, 1997).

\section{Inoculum preparation}

Inoculum was prepared according to the method described by Ramires-Coronel et al. (2003). The fungal isolate was cultivated on PDA slant then incubated for 4 days at $30^{\circ} \mathrm{C}$ until a good sporulation was obtained. Spores were then scraped into a sterile $0.02 \%$ Tween 80 solution (Ramires-Coronel et al., 2003) and counted by Neubauer chamber method, the suitable volume which contains the needed number of spores was calculated (Harisha, 2007).

\section{Harvesting the enzyme and enzyme assay}

The fermentation medium was filtered through Whatman No.1 filter paper. The obtained filtrate was used for extracellular tannase determination (Gupta et al., 1997). Intracellular tannase was extracted from the mycelium (Sharma et al., 2000).

Tannase activity was assayed using rhodanine spectrophotometric method (Sharma et al., 2000). Methyl gallate was used as substrate. The method is based on the chromogen formation between gallic acid and rhodanine. The method was modified by using $0.2 \mathrm{~mL}$ of $1 \mathrm{~N}$ instead of $0.5 \mathrm{~N}$ of potassium hydroxide solution for enhancing the colour formation. One unit (U) of the enzyme was defined as micromoles of gallic acid formed per minute by one $\mathrm{ml}$ of enzyme extract under optimum conditions of tannase activity.

\section{Standard protocol}

Sterilized MCDM medium ( $\mathrm{pH} 4.5 \pm 0.2$ ) containing $1 \%$ filter sterilized tannic acid was distributed in $50 \mathrm{~mL}$ portions into $250 \mathrm{~mL}$ Erlenmeyer flasks. Each flask was inoculated with $5 \times 10^{7}$ spores from 4-days-old culture and incubated for $96 \mathrm{~h}$ at $30^{\circ} \mathrm{C}$ (Saxena and Saxena, 2004). The incubation was carried out with intermittent shaking three times a day at $200 \mathrm{rpm}$ for 2 min each time using an orbital incubator (Model INR-200, Gallenkamp,UK). Deviations from this standard protocol have been indicated in respective experiments. After harvesting the culture filtrate, the enzyme was assayed.

\section{Effect of fermentation techniques and agitation condition}

The LSF was carried out statically without agitation (Bradoo et al., 1997). Whereas, SmF was carried out under continuous and intermittent shaking. Continuous shaking was carried out at $120 \mathrm{rpm}$ in the orbital incubator, while intermittent shaking was carried out as mentioned in the standard protocol. The SSF was carried out using natural (wheat bran) and synthetic solid supports (polyurethane foam and sponge) impregnated with the MCDM medium (Pinto et al., 2001; Ramirez-Coronel et al., 2003). The extracellular and intracellular tannase activities per $50 \mathrm{~mL}$ culture or mycelium produced from $50 \mathrm{~mL}$ culture were determined.

The enzyme produced by SSF using either PUF or sponge as solid supports was obtained by compressing PUF or sponge separately in a Buchner funnel. The extract was then centrifuged $(5000 \mathrm{~g}, 15 \mathrm{~min})$ then the supernatant was used for extracellular tannase assay (Ramirez-Coronel et al., 2003). Enzyme produced by SSF using wheat bran was extracted from the fermented matter according to the method of Pinto et al. (2001) by adding $50 \mathrm{~mL}$ of $0.05 \mathrm{M}$ citrate buffer ( $\mathrm{pH}$ 5.0). The flasks were then shaked in the orbital shaker $(200 \mathrm{rpm})$ for one $\mathrm{h}$ at $30^{\circ} \mathrm{C}$. The crude enzyme was separated by filtration over Whatman No.1 filter paper. The filtrate was used for extracellular tannase assay.

\section{Effect of tannin sources}

The effect of various tannins-containing natural substrates was studied on enzyme production using $\mathrm{SmF}$ and SSF techniques. These substrates were dried powder of: pomegranate peels, persimmon fruits, river-red-gum leaves and unripe date. Tannic acid was used as a control. In SmF experiments, amounts of natural substrates added to the MCDM medium, to give $1 \%$ tannins, were calculated according to their measured contents of tannins using protein precipitation method (Hagerman and Butler, 1978). In SSF experiments, natural substrates were used as sole carbon sources and natural solid supports. Fermentation was carried out in sterilized $250 \mathrm{~mL}$ Erlenmeyer flasks contained amounts of tannins-containing natural substrate powders that give $1 \%$ final concentrations of tannins in the medium. The solid substrates were moistened with $20 \mathrm{~mL}$ of sterilized MCDM medium without tannic acid. Flasks were incubated statically.

\section{Effect of adding carbohydrates incorporation with tannic acid}

Several carbohydrates were separately incorporated at $0.2 \%(\mathrm{w} / \mathrm{v})$ concentration into MCDM medium. These 
carbohydrates comprised four monosaccharides (fructose, galactose, glucose and xylose); two disaccharides (lactose and sucrose); a polysaccharide (starch) and a sugar alcohol (mannitol).

\section{Effect of nitrogen source type}

The effect of various nitrogen sources $(0.99 \mathrm{~g}$ nitrogen/L) was studied on tannase production. Four inorganic nitrogen sources (ammonium chloride, ammonium nitrate and potassium nitrate as well as sodium nitrate as control) and seven organic nitrogen sources (beef extract, cotton seed meal, flax seed meal, peptone, soy bean meal, urea and yeast extract) were tested. Determinations of total nitrogen contents in all organic nitrogen sources except urea were carried out by micro Kjeldahl method (AOAC International, 2000).

\section{Effect of divalent cations}

Various divalent cations $(0.2 \%)$ were added separately to study their effect on the enzyme production. These included chlorides of $\mathrm{Ca}^{2+}, \mathrm{Cd}^{2+}, \mathrm{Cu}^{2+}, \mathrm{Hg}^{2+}, \mathrm{Mg}^{2+}$, sulphates of $\mathrm{Fe}^{2+}, \mathrm{Zn}^{2+}$ and acetate of $\mathrm{Pb}^{2+}$.

\section{Effect of fermentation temperature and fermentation time}

The effect of five fermentation temperatures $(20,25$, 30,35 and $\left.40{ }^{\circ} \mathrm{C}\right)$ and five fermentation times $(24,48,72$, 96 and $120 \mathrm{~h}$ ) were studied simultaneously by a full factorial experiment using split plot design in order to study the main effect of each variable separately and the interaction between these two variables. Five incubators were adjusted at the studied temperatures. At each incubator, five $250 \mathrm{~mL}$ Erlenmeyer flasks each containing $50 \mathrm{~mL}$ of MCDM medium, one flask for each fermentation time, were incubated. Incubation and agitation was carried out as mentioned in standard protocol. Each flask represents an experimental unit. The extracellular tannase activity $/ 50 \mathrm{~mL}$ was determined after $24 \mathrm{~h}$ intervals up to $120 \mathrm{~h}$ for each fermentation temperature. This factorial experiment was repeated three times (three blocks) and the average of extracellular tannase activity was measured for each experimental unit.

\section{Statistical analysis}

Each experiment was carried out in triplicates and the values were averaged. The one way analysis of variance (ANOVA) was carried out by STATESTICA 7.0 software (StatSoft, Inc., USA) and differences among the means were determined for significance at $\mathrm{p}<0.05$ using Fisher least significant difference test $\left(\operatorname{LSD}_{0.05}\right)$.

\section{Results and Discussion}

\section{Effect of fermentation techniques and agitation condition}

There is a significant effect $(\mathrm{p}<0.05)$ of the fermentation technique on the production of Aspergillus niger Van Tieghem tannase (Table 1). Tannase activity was mainly attributed to the secretion of extracellular tannase either under LSF (36.9 U/ $50 \mathrm{~mL})$ or SmF (73-290 U/50 mL). Low level of intracellular tannase activity $(7.1-11.7 \mathrm{U} / 50 \mathrm{~mL})$ was produced by the fungus (Table 1).

Among the tested fermentation techniques, $\mathrm{SmF}$ gave the highest total tannase activity either under intermittent shaking (298.4 U/50 mL) or continuous shaking $(80.2 \mathrm{U} / 50 \mathrm{~mL})$ followed by LSF technique $(48.6 \mathrm{U} / 50 \mathrm{~mL})$. The ability of SmF technique to enhance tannase production over LSF technique was reported for Aspergillus niger PKL104 (Lekha et al., 1994) and Aspergillus niger Van Tieghem MTCC 2425 (Rana and Bhat, 2005). Solid state fermentation technique (using PUF, sponge and wheat bran

Table 1 - Effect of fermentation technique and agitation condition on tannase production by Aspergillus niger Van Tieghem.

\begin{tabular}{|c|c|c|c|}
\hline Fermentation technique & $\begin{array}{c}\text { Mean of extracellular } \\
\text { tannase activity } \\
(\mathrm{U} / 50 \mathrm{~mL} \pm \mathrm{SD})\end{array}$ & $\begin{array}{c}\text { Mean of intracellular } \\
\text { tannase activity } \\
(\mathrm{U} / 50 \mathrm{~mL} \pm \mathrm{SD})\end{array}$ & $\begin{array}{c}\text { Mean of total tannase } \\
\text { activity } \\
(\mathrm{U} / 50 \mathrm{~mL} \pm \mathrm{SD})\end{array}$ \\
\hline Liquid surface fermentation, LSF (static condition) & $36.9 \pm 3^{c}$ & $11.7 \pm 0.2^{\mathrm{a}}$ & $48.6 \pm 3.2^{\mathrm{c}}$ \\
\hline Submerged fermentation, $\mathrm{SmF}$ (intermittent shaking) & $290.2 \pm 32.4^{\mathrm{a}}$ & $8.2 \pm 0.3^{\mathrm{b}}$ & $298.4 \pm 32.6^{\mathrm{a}}$ \\
\hline Submerged fermentation, $\mathrm{SmF}$ (continuous shaking) & $73.2 \pm 1.4^{\mathrm{b}}$ & $7.1 \pm 0.6^{\mathrm{c}}$ & $80.2 \pm 1.8^{\mathrm{b}}$ \\
\hline Solid state fermentation, SSF (using PUF as solid support) & $13.6 \pm 1.9^{\mathrm{cd}}$ & nd & $13.6 \pm 1.9^{\mathrm{d}}$ \\
\hline Solid state fermentation, SSF (using Sponge as solid support) & $11.5 \pm 1.1^{\mathrm{d}}$ & nd & $11.5 \pm 1.1^{\mathrm{d}}$ \\
\hline Solid state fermentation, SSF (using wheat bran as solid support) & $7.1 \pm 1.4^{\mathrm{e}}$ & nd & $7.1 \pm 1.4^{\mathrm{d}}$ \\
\hline
\end{tabular}

The same superscript letters in each column indicate that there is no significant difference at $\mathrm{p}<0.05$.

Fermentation conditions: tannic acid concentration, $1 \%$; initial $\mathrm{pH}, 4.5 \pm 0.2$; incubation temperature, $30^{\circ} \mathrm{C}$; inoculum size $5 \times 10^{7} \mathrm{spores} / 50 \mathrm{~mL}$. LSF and SSF techniques were incubated statically whereas SmF technique was incubated under continuous shaking at 120 rpm or intermittent shaking 3 times a day at $200 \mathrm{rpm}$ for 2 min each time.

LSF and SmF techniques were carried out in $250 \mathrm{~mL}$ Erlenmeyer flasks containing $50 \mathrm{~mL}$ of the MCDM medium. SSF technique was carried out in 250 $\mathrm{mL}$ Erlenmeyer flasks containing $20 \mathrm{~g}$ of wheat bran moistened with $20 \mathrm{~mL}$ of sterilized MCDM medium, or containing $5 \mathrm{~g}$ of PUF or sponge impregnated with $50 \mathrm{~mL}$ of sterilized MCDM medium.

nd: not determined. 
as solid supports) exhibited the lowest tannase activities (13.6, 11.5 and $7.1 \mathrm{U} / 50 \mathrm{~mL}$, respectively). This result is coinciding with that reviewed by Chaterjee et al. (1996) that $\mathrm{SmF}$ technique has high efficiency over SSF technique for tannase production. Also, Rana and Bhat (2005) found that tannase production by Aspergillus niger Van Tieghem MTCC 2425 was higher in SmF than SSF. On the other hand, these results are in contrast with some previous reports which confirmed that tannase production by SSF was higher than SmF system (Kar and Banerjee, 2000; Lekha et al., 1994). There was no significant $(\mathrm{p}<0.05)$ difference between SSF using PUF or sponge as solid supports on production of extracellular tannase. Sponge can be used instead of PUF since it is less expensive and more available than PUF. It is worthy to mention that this is the first time to use the sponge as a synthetic solid support in SSF.

With respect to the effect of agitation on tannase production by Aspergillus niger Van Tieghem under SmF technique, the results showed that tannase production under $\mathrm{SmF}$ with intermittent shaking is significantly $(\mathrm{p}<0.05)$ higher than that attained using $\mathrm{SmF}$ with continuous shaking. There is no previous work studied the effect of agitation condition on tannase production using $\mathrm{SmF}$ technique except that of Hadi et al. (1994). They found that the maximum production of tannase by Rhizopus oryzae occurred in shaking condition as compared with stationary and intermittent shaking conditions. These results disagree with those obtained in the present study.

\section{Effect of tannin sources}

Results presented in Table 2 revealed the following: The maximum extracellular tannase activity $(305 \mathrm{U} / 50 \mathrm{~mL})$ was attained in the MCDM medium containing tannic acid as tannins source using $\mathrm{SmF}$ technique (intermittent shaking). It was significantly $(p<0.05)$ higher than all of the other media with tannins-containing substrates either in $\mathrm{SmF}$ or SSF techniques.

The superiority of tannic acid, as a tannin source for tannase production over all studied natural tannin sources, may be due to the naturally occurrence of simple sugars in the studied natural tannins sources. These simple sugars can be used easily by the fungus for growth.

Many tannins-containing plant residues were previously studied as natural alternative tannin sources for tannase production. Some of them gave tannase activity higher than that obtained with tannic acid such as Caesalpina digyna seed cover powder (Kar and Banerjee2000), infusions from sorghum, pecan peels and creosote bush (Belmares-Cerda et al., 2003) but others were not an effective carbon source for tannase production such as valonia tannins (Huang and Borthwick, 2005).

\section{Effect of adding carbohydrates incorporation with tannic acid}

All the added carbohydrates showed significant $(p<0.05)$ adverse effects on the production of tannase where, the control (without added sugar) exhibited the highest extracellular tannase production $(283.9 \mathrm{U} / 50 \mathrm{~mL})$. The inhibition effect varied significantly with the variation of carbohydrate type (Table 3). The highest reduction in tannase activity was for fructose (54.8\%) followed by mannitol (52.8\%), lactose (39.9\%), galactose $(20.4 \%)$, glucose $(20.15 \%)$, sucrose $(12.6 \%)$, xylose $(10.8 \%)$ and starch $(10.4 \%)$.

Similar results were reported by many investigators. Bradoo et al. (1997) reported that the addition of $0.2 \%$ of various mono and polysaccharides (arabinose, fructose, galactose, xylose, manitol, carboxy methyl cellulose and starch) to MCDM medium containing 2\% tannic acid had negative effect on enzyme production by Aspergillus japonicas. Using $0.1 \%$ additional carbon sources (arabinos,

Table 2 - Effect of tannins source on tannase production by Aspergillus niger Van Tieghem using SmF and SSF techniques.

\begin{tabular}{lcc}
\hline Substrate & Fermentation technique & Mean of extracellular tannase (U/50 mL \pm SD) \\
\hline Tannic acid (MCDM medium) & SmF & $305.12 \pm 4.9^{\mathrm{a}}$ \\
Powder of dried persimmon (Diospyrus kak) & $\mathrm{SmF}$ & $2.79 \pm 0.5 \mathrm{~d}^{\mathrm{e}}$ \\
fruits & $\mathrm{SSF}$ & $0.003 \pm 0.0^{\mathrm{e}}$ \\
& $\mathrm{SmF}$ & $15.04 \pm 0.7^{\mathrm{c}}$ \\
Powder of dried pomegranate peels (Punica & $\mathrm{SSF}$ & $17.36 \pm 1.0^{\mathrm{c}}$ \\
granatum) & $\mathrm{SmF}$ & $81.71 \pm 2.4^{\mathrm{b}}$ \\
Powder of dried river-red-gum (Eucalyptus & $\mathrm{SSF}$ & $4.49 \pm 0.1^{\mathrm{d}}$ \\
camaldulensis Dehn) leaves & $\mathrm{SmF}$ & $0.14 \pm 0.0^{\mathrm{e}}$ \\
Powder of dried unripe date & $\mathrm{SSF}$ & $0.01 \pm 0.0^{\mathrm{e}}$ \\
\hline
\end{tabular}

The same superscript letters indicate that there is no significant difference at $\mathrm{p}<0.05$.

Fermentation conditions: tannic acid or tannins concentration, $1 \%$; initial $\mathrm{pH}, 4.5 \pm 0.02$; incubation temperature, $30{ }^{\circ} \mathrm{C}$; inoculum size $5 \times 10^{7}$ spores $/ 50 \mathrm{~mL}$. SSF techniques were incubated statically whereas $\mathrm{SmF}$ technique was incubated under intermittent shaking 3 times a day at $200 \mathrm{rpm}$ for 2 min each time. 
Table 3 - Effect of addition carbohydrates incorporation with tannic acid on tannase production by Aspergillus niger Van Tieghem.

\begin{tabular}{lc}
\hline Added carbohydrate & $\begin{array}{c}\text { Mean of extracellular tannase } \\
(\mathrm{U} / 50 \mathrm{~mL} \pm \mathrm{SD})\end{array}$ \\
\hline None* & $283.9 \pm 8.9^{\mathrm{a}}$ \\
Fructose & $128.3 \pm 15.7^{\mathrm{e}}$ \\
Galactose & $226.1 \pm 18.0^{\mathrm{c}}$ \\
Glucose & $226.7 \pm 10.3^{\mathrm{c}}$ \\
Xylose & $253.2 \pm 9.2^{\mathrm{b}}$ \\
Lactose & $170.7 \pm 21.0^{\mathrm{d}}$ \\
Sucrose & $248.0 \pm 20.0^{\mathrm{bc}}$ \\
Starch & $254.3 \pm 13.8^{\mathrm{b}}$ \\
Mannitol & $135.6 \pm 8.6^{\mathrm{e}}$ \\
\hline
\end{tabular}

The same superscript letters indicate that there is no significant difference at $\mathrm{p}<0.05$. Fermentation conditions: tannic acid concentration, $1 \%$; added carbohydrate, $0.2 \%(\mathrm{w} / \mathrm{v})$; initial $\mathrm{pH}, 4.5 \pm 0.2$; incubation temperature, $30^{\circ} \mathrm{C}$; inoculum size $5 \times 10^{7}$ spores $/ 50 \mathrm{~mL}$; agitation condition, under intermittent shaking 3 times a day at $200 \mathrm{rpm}$ for 2 min each time.

*MCDM medium with $1 \%$ tannic acid, without any added carbohydrates.

lactose, maltose, mannitol, sucrose and xylose) incorporation with tannic acid (1\%) in the tannic acid medium exhibited a negative effect on tannase formation by Aureobasidium pullulans (Banerjee and Pati, 2007). Raaman et al. (2010) revealed that tannase production by Paecilomyces variotii was decreased by adding $1 \%$ carbohydrates (arabinose, fructose, lactose, maltose, mannitol, raffinose, rhamnose, sorbose, sucrose, starch and xylose) incorporation with tannic acid (1.5\%) under SmF technique using tannic acid medium . In contrast, Bradoo et al. (1997) reported that addition of $0.2 \%$ glucose to MCDM medium containing 2\% tannic acid increased tannase secretion by Aspergillus japonicas. Also, it was found that adding $0.1 \%$ of either glucose or sucrose to $1 \%$ tannic acid medium induced the Aureobasidium pullulans tannase (Banerjee and Pati, 2007). Rodrigues et al. (2008) found that supplementation with $1 \%(\mathrm{w} / \mathrm{v})$ starch or sucrose increased enzyme production by Aspergillus oryzae.

\section{Effect of nitrogen source type}

The results shown in Table 4 revealed that the type of nitrogen source significantly $(\mathrm{p}<0.05)$ affect tannase production. The maximum extracellular tannase activity (284.3 U/50 mL) was attained by sodium nitrate. The stimulation effect of sodium nitrate on the synthesis of fungal tannase was reported for Rhizopus oryzae (Hadi et al., 1994) and Aspergillus japonicas (Bradoo et al., 1997). On the other hand, Banerjee and Pati (2007) mentioned that di-ammonium hydrogen phosphate was more effective than sodium nitrate to enhance tannase production by Aureobasidium pullulans.

It is evident from the results of the present study that the inorganic nitrogen sources enhanced tannase elabora-
Table 4 - Effect of nitrogen source type on tannase production by Aspergillus niger Van Teighem.

\begin{tabular}{llc}
\hline Nitrogen source & & $\begin{array}{c}\text { Mean of extracellular tannase } \\
\text { activity (U/50 mL } \pm \mathrm{SD})\end{array}$ \\
\hline Inorganic sources & *Sodium nitrate & $284.3 \pm 5.7^{\mathrm{a}}$ \\
& Ammonium chloride & $259.4 \pm 6.6^{\mathrm{b}}$ \\
& Ammonium nitrate & $265.1 \pm 4.2^{\mathrm{b}}$ \\
& Potassium nitrate & $276.2 \pm 10.2^{\mathrm{a}}$ \\
Organic sources & Urea & $244.4 \pm 7.9^{\mathrm{c}}$ \\
& Beef extract & $134.4 \pm 6.2^{\mathrm{g}}$ \\
& Cotton seeds meal & $193.8 \pm 4.0^{\mathrm{de}}$ \\
& Flax seeds meal & $202.2 \pm 6.2^{\mathrm{d}}$ \\
& Peptone & $120.6 \pm 4.6^{\mathrm{h}}$ \\
& Soy bean meal & $183.6 \pm 6.5^{\text {ef }}$ \\
& Yeast extract & $173.8 \pm 7.1^{\mathrm{f}}$ \\
\hline
\end{tabular}

The same superscript letters indicate that there is no significant difference at $\mathrm{p}<0.05$.

Fermentation conditions: tannic acid concentration, $1 \%$; initial pH, $4.5 \pm$ 0.2 ; incubation temperature, $30^{\circ} \mathrm{C}$; inoculum size $5 \times 10^{7}$ spores $/ 50 \mathrm{~mL}$; agitation condition, under intermittent shaking 3 times a day at $200 \mathrm{rpm}$ for 2 min each time.

*MCDM medium with $1 \%$ tannic acid containing $6 \mathrm{~g} / \mathrm{L}$ sodium nitrate.

tion more than the organic nitrogen sources. Among the tested organic nitrogen sources, peptone demonstrated the least tannase production (Table 4). In contrast, Huang and Borthwick (2005) reported that the organic nitrogen sources were more favorable for the secretion of tannase by Aspergillus SH6 especially peptone.

\section{Effect of divalent cations}

The addition of divalent cations had a significant $(p<0.05)$ effect on the extracellular tannase production (Table 5). All studied divalent cations significantly $(\mathrm{p}<0.05)$ decreased tannase production except $\mathrm{Pb}^{2+}$ and $\mathrm{Mg}^{2+}$ which resulted in non- significant decrease ratio of tannase activity (3.9\% and $7.03 \%$, respectively). The addition of $\mathrm{Hg}^{2+}$ and $\mathrm{Cu}^{2+}$ to the MCDM medium drastically reduced tannase activity by $89.1 \%$ and $83 \%$, respectively. Similar result was obtained by Bradoo et al. (1997). They found that all studied divalent cations $\left(\mathrm{Ca}^{2+}, \mathrm{Cd}^{2+}, \mathrm{Cu}^{2+}\right.$, $\mathrm{Fe}^{2+}, \mathrm{Hg}^{2+}, \mathrm{Mg}^{2+}, \mathrm{Pb}^{2+}$ and $\mathrm{Zn}^{2+}$ ) decreased Aspergillus japonicas tannase production under $\mathrm{SmF}$ technique using MCDM medium.

\section{Effect of fermentation temperature and fermentation time}

Data presented in Table 6 and ANOVA (Table 7) show that the main effects of fermentation temperature and fermentation time, were significant $(p<0.05)$ on tannase production. In addition, the interaction between them was significant $(\mathrm{p}<0.05)$ on tannase production. The maximum mean of extracellular tannase production was attained at 
Table 5 - Effect of divalent cations on tannase production by Aspergillus niger Van Tieghem.

\begin{tabular}{lc}
\hline Type of divalent cation & $\begin{array}{c}\text { Mean of extracellular tannase } \\
(\mathrm{U} / 50 \mathrm{~mL} \pm \mathrm{SD})\end{array}$ \\
\hline $\mathrm{None}^{*}$ & $282.9 \pm 11.3^{\mathrm{a}}$ \\
$\mathrm{Ca}^{2+}$ & $221.8 \pm 18.6^{\mathrm{b}}$ \\
$\mathrm{Cd}^{2+}$ & $127.4 \pm 12.3^{\mathrm{c}}$ \\
$\mathrm{Cu}^{2+}$ & $48.1 \pm 1.4^{\mathrm{d}}$ \\
$\mathrm{Fe}^{2+}$ & $211.9 \pm 19.6^{\mathrm{b}}$ \\
$\mathrm{Hg}^{2+}$ & $30.7 \pm 0.6^{\mathrm{d}}$ \\
$\mathrm{Mg}^{2+}$ & $263 \pm 17.2^{\mathrm{a}}$ \\
$\mathrm{Pb}^{2+}$ & $271.8 \pm 13.1^{\mathrm{a}}$ \\
$\mathrm{Zn}^{2+}$ & $229.9 \pm 32.6^{\mathrm{b}}$ \\
\hline
\end{tabular}

The same superscript letters indicate that there is no significant difference at $\mathrm{p}<0.05$.

Fermentation conditions: tannic acid concentration, 1\%; individual divalent cations, $0.2 \%(\mathrm{w} / \mathrm{v})$; initial $\mathrm{pH}, 4.5 \pm 0.2$; incubation temperature, $30{ }^{\circ} \mathrm{C}$; inoculums size $5 \times 10^{7}$ spores $/ 50 \mathrm{~mL}$; agitation condition, under intermittent shaking 3 times a day at $200 \mathrm{rpm}$ for 2 min each time. *MCDM medium with $1 \%$ tannic acid, without divalent cations addition.

temperature $35^{\circ} \mathrm{C}$, whereas lower and higher temperatures decreased tannase production. The maximum mean of extracellular tannase production was attained after $120 \mathrm{~h}$ while, the lower mean of extracellular tannase production was attained after $24 \mathrm{~h}$ of incubation (Table 6). The analysis of variance (Table 7) confirmed the significance of the interaction between these two variables. Although the main effect of fermentation time showed that $120 \mathrm{~h}$ exhibited the highest extracellular tannase production, the interaction with the effect of fermentation temperature was altered the effect of fermentation time on tannase production, the highest tannase production $(312.7 \mathrm{U} / 50 \mathrm{~mL})$ was attained in shorter time $(96 \mathrm{~h})$ when the fermentation temperature was at its optimum level $\left(35^{\circ} \mathrm{C}\right)$ as presented in Table 6 .

Concerning the independent effect of fermentation temperature on tannase production, Banerjee et al. (2005) reported that fermentation temperature affects the fungal growth, spore formation, germination, microbial physiol-
Table 7 - Analysis of variance (ANOVA) for split plot experiment studying the effect of fermentation time and temperature on tannase production by Aspergillus niger Van Tieghem.

\begin{tabular}{lccccc}
\hline SOV & DF & SS & MS & F & $p$ \\
\hline Block & 2 & 814 & 406.81 & 8.18 & $0.001051^{*}$ \\
$\mathrm{~T}$ & 4 & 54802 & 13700.57 & 275.49 & $0.000000^{*}$ \\
Block*T & 8 & 503 & 62.85 & & \\
D & 4 & 212759 & 53189.82 & 1069.572 & $0.000000^{*}$ \\
T*D & 16 & 7500 & 468.75 & 9.426 & $0.000000^{*}$ \\
Error & 40 & 1989 & 49.73 & & \\
Total & 74 & 3802061 & & & \\
\hline
\end{tabular}

Blocks: Replicates.

$\mathrm{T}$ : The main effect of fermentation temperature.

D: the main effect of fermentation time.

$\mathrm{T} * \mathrm{D}$ : The interaction effect of fermentation temperature and fermentation time.

*: Significant difference at $(\mathrm{p}>0.05)$.

ogy, and thus product formation. Therefore, maintenance of an optimal process temperature is considered as one of the major factors which affect the economics of the microbial enzymes production process. Consequently, the effect of this factor on tannase production was extensively studied by many investigators. They found that the optimum temperature for maximum production of Aspergillus spp. tannase ranged from 25 to $30{ }^{\circ} \mathrm{C}$ (Kumar et al., 2007; Manjit et al., 2008; Sabuet al., 2005). The isolated strain of Aspergillus niger Van Teighem used in the present study has optimum temperature of $35^{\circ} \mathrm{C}$. This is an advantageous point due to reduction of the cooling cost during production on commercial scale.

Regarding the effect of fermentation time on tannase production, the obtained results showed that tannase production, at $35^{\circ} \mathrm{C}$, was peaked at the optimum fermentation time $(96 \mathrm{~h})$ then showed gradual decrease. This result is in agreement with other studies (Huang and Borthwick, 2005; Kumar et al., 2007; Rodrigues et al., 2007). The reasons of this phenomenon were illustrated by many investigators. Hadi et al. (1994) revealed that this might be due to catabolic repression and substrate scarcity in the medium.

Table 6 - Effect of fermentation temperature and fermentation time on tannase production by Aspergillus niger Van Tieghem.

\begin{tabular}{lccccc}
\hline \multirow{2}{*}{$\mathrm{T}\left({ }^{\circ} \mathrm{C}\right)$} & \multicolumn{5}{c}{ *Mean of extracellular tannase $(\mathrm{U} / 50 \mathrm{~mL} \pm \mathrm{SD})$} \\
\cline { 2 - 6 } & \multicolumn{5}{c}{$\mathrm{D}(\mathrm{h})$} \\
\cline { 2 - 6 } & 24 & 48 & 72 & 96 & 120 \\
\hline 20 & $106.6 \pm 6.7$ & $139.3 \pm 9.2$ & $176.5 \pm 8.2$ & $207.2 \pm 7.1$ & $248 \pm 11.4$ \\
25 & $126.6 \pm 6.1$ & $171.8 \pm 4.4$ & $222.8 \pm 8.7$ & $258.8 \pm 8.8$ & $265.6 \pm 17.8$ \\
30 & $153.9 \pm 5.8$ & $213.5 \pm 4.4$ & $255.6 \pm 6.8$ & $283.3 \pm 5.1$ & $284.6 \pm 10.9$ \\
35 & $158.5 \pm 9.1$ & $220.2 \pm 6.1$ & $271.9 \pm 5.6$ & $312.7 \pm 6.5$ & $304.2 \pm 6.5$ \\
40 & $115.5 \pm 8.8$ & $181.2 \pm 7.5$ & $195.6 \pm 9$ & $256.2 \pm 5.8$ & $288.8 \pm 4.9$ \\
\hline
\end{tabular}

*Mean of triplicates (blocks). D: Fermentation time (h). T: Fermentation temperature $\left({ }^{\circ} \mathrm{C}\right)$. 
Huang and Borthwick (2005) suggested that this may be due to scarcity in nitrogen source, while Kumar et al. (2007) and Rodrigues et al. (2007) mentioned that it may be caused by accumulation of toxic metabolites secreted during fermentation.

Concerning the interaction between temperature and time of fermentation process on tannase production, there are no previous investigations focused on this relationship except the study of Lekha et al. (1994). They studied the effect of interaction between other five variables on Aspergillus niger PKL tannase production in wheat bran solid medium.

In conclusion, the optimum qualitative variables affecting tannase production by a newly isolate of Aspergillus niger Van Tieghem were: submerged fermentation under intermittent shaking in a medium containing tannic acid and sodium nitrate as carbon and nitrogen sources, respectively. This study indicated that tannase production at optimum fermentation temperature $\left(35^{\circ} \mathrm{C}\right)$ was peaked at the optimum fermentation time $(96 \mathrm{~h})$. Further studies to optimize the rest of quantitative variables affecting tannase production by this isolate, is needed.

\section{References}

Aboubakr HA, El-Banna AA, El-Sahn MA (2012) Tannase-Producing Fungi: Isolation, Screening, Identification and Optimizing the Enzyme Production. LAMBERT Academic Publishing, Saarbrücken, 188 pp.

Aguilar CN, Gutiérrez-Sanchez G (2001) Review: Sources, properties, applications and potentioal uses of tannin acyl hydrolase. Food Sci Technol Int 7:375-382.

Aguilar CN, Rodriguez R, Gutiérrez-Sanchez G, Augur C, Favela-Torres E, Prado-Barragan L, Ramirez-Coronel A, Contreras-Esquivel JC (2007) Microbial tannases, advances and perspectives. Appl Microbiol Biotechnol 76:47-59.

Albertse EH (2002) Cloning, Expression and Characterization of Tannase from Aspergillus Species. M.Sc. Thesis, Faculty of Natural and Agricultural Sciences, University of the Free State, South Africa pp 24.

AOAC International (2000) Official Methods of Analysis of AOAC International. 17th ed. Association of Official Analytical Chemists, Gaithersburg.

Bajpai B, Patil S (1997) Induction of tannin acyl hydrolase (EC 3.1.1.20) activity in some members of fungi imperfecti. Microbial Technology 20:612-614.

Banerjee D, Mondal KC, Pati BR (2001) Production and characterization of extracellular and intracellular tannase from newly isolated Aspergillus aculeatus DBF 9. J Basic Microbiol 41:313-318.

Banerjee R, Mukherjee G, Patra KC (2005) Microbial transformation of tannin-rich substrate to gallic acid through co-culture method. Bioresource Technol 96:949-953.

Banerjee D, Pati BR (2007) Optimization of tannase production by Aureobasidium pullulans DBS66. J Microbiol Biotechnol 17:1049-1053.

Belmares-Cerda R, Reyes-Vega ML, Contreras-Esquivel JC, Rodriguez-Herrera R, Aguilar CN (2003) Effect of carbon source on tannase production by two strains of Aspergillus niger. Revista Mexicana de Ingenieria Quimica 2:95-100.

Bradoo S, Gupta R, Saxena RK (1996) Screening of extracellular tannase producing fungi, Development of a rapid and simple plate assay. J Gen Appl Microbiol 42:325-329.

Bradoo S, Gupta R, Saxena RK (1997) Parametric optimization and biochemical regulation of extracellular tannase from Aspergillus japonicus. Process Biochem 32:135-139.

Chatterjee R, Dutta A, Banerjee R, Bhattacharyya BC (1996) Production of tannase by solid-state fermentation. Bioprocess Biosyst Eng 14:159-162.

Gupta R, Bradoo S, Saxena RK (1997) Rapid purification of extracellular tannase using polyethylene glycol- tannic acid complex. Lett Appl Microbiol 24:253-255.

Hadi TA, Banerjee R, Bhattacharyya BC (1994) Optimization of tannase biosynthesis by a newly isolated Rhizopus oryzae. Bioprocess Biosyst Eng 11:239-243.

Hagerman AE, Butler LG (1978) Protein precipitation method for the quantitative determination of tannins. J. Agric Food Chem 26:809-812.

Harisha S (2007) Biotechnology Procedures and Experimental Handbook. Infinity Science Press, Canada, pp 149-152.

Huang W, Ni J, Borthwick AGL (2005) Biosynthesis of valonia tannin hydrolase and hydrolysis of valonia tannin to ellagic acid by Aspergillus SHL 6. Process Biochem 40:1245-1249.

Kar B, Banerjee R (2000) Biosynthesis of tannin acyl hydrolase from tannin- rich forest residue under different fermentation conditions. J Ind Microbiol Biotechnol 25:29-38.

Kumar R, Sharma J, Singh R (2007) Production of tannase from Aspergillus ruber under solid-state fermentation using jamun (Syzygium cumini) leaves. Mycol Res 162:384-390.

Lekha PK, Chand N, Lonsane BK (1994) Computerized study of interactions among factors and their optimization through response surface methodology for the production of tannin acyl hydrolase by Aspergillus niger PKL 104 under solid state fermentation. Bioprocess Biosyst Eng 11:7-15.

Manjit YA, Aggarwal NK, Kumar K, Kumar A (2008) Tannase production by Aspergillus fumigates MA under solid-state fermentation. World J Microbiol Biotechnol 24:3023-3030.

Pinto GAS, Leite SGF, Terzi SC, Couri S (2001) Selection of tannase-producing Aspergillus niger strains. Braz J Microbiol 32:24-26.

Raaman N, Mahendran B, Jaganathan C, Sukumar S, Chandrasekaran V (2010) Optimization of extracellular tannase production from Paecilomyces variotii. World J Microbiol Biotechnol 26:1033-1039.

Ramirez-Coronel MA, Viniegra-Gonzalez G, Darvill A, Augur C (2003) A novel tannase from Aspergillus niger with betaglucosidase activity. Microbiol 149:2941-2946.

Rana NK, Bhat TK (2005) Effect of fermentation system on the production and properties of tannase of Aspergillus niger Van Tieghem MTCC 2425. J Gen Appl Microbiol 51:203212.

Rodrigues THS, Dantas MAA, Pinto GAS, Goncalves LRB (2007) Tannase production by solid state fermentation of cashew apple bagasse. Appl Biochem Biotechnol 7:675-688.

Rodrigues THS, Pinto GAS, Goncalves LRB (2008) Effects on inoculums concentration, temperature and carbon sources on tannase production during solid state fermentation of cashew apple bagasse. Biotechnol Bioprocess Eng 13:571576. 
Rodriguez H, de las Rivas B, Gomez-Cordoves C, Munoz R (2008) Characterization of tannase activity in cell-free extracts of Lactobacillus plantarum CECT 748T. Inter J Food Microbiol 121:92-98.

Sabu A, Pandey A, Daud MJ, Szakacs G (2005) Tamarind seed powder and palm kernel cake, two novel agro residues for the production of tannase under solid state fermentation by Aspergillus niger ATCC 16620. Bioresource Technol 96:1223-1228.

Saxena S, Saxena RK (2004) Statistical optimization of tannase production from Penicillium variable using fruits (Chebulic myrobalan) of Terminalia chebula. Biotechnol Appl Biochem 39:99-106.

Sharma S, Agarwal L, Saxena RK (2007) Statistical optimization for tannase production from Aspergillus niger under submerged fermentation. Ind J Microbiol 47:132-138.

Sharma S, Agarwal L, Saxena RK (2008) Purification, immobilization and characterization of tannase from Penicillium variable. Bioresource Technol 99:2544-2551.

Sharma S, Bhat TK, Dawra RK (2000) A spectrophotometric method for assay of tannase using rhodanine. Anal Biochem 279:85-89.

All the content of the journal, except where otherwise noted, is licensed under a Creative Commons License CC BY-NC. 